\title{
Growth, Phenology and Yield Component of Barley (Hordeum vulgare L.) Genotypes as Affected by Fertilizer Types Under Acidic Soil
}

\author{
Hailu Hameso ${ }^{1}$, Waleligh Worku², Tewodros Ayalew ${ }^{2}$ \\ ${ }^{1}$ Faculty of Agriculture, Daye Campus, Hawassa University, Daye, Ethiopia \\ ${ }^{2}$ Schools of Plant and Horticulture Sciences, College of Agriculture, Hawassa University, Hawassa, Ethiopia \\ Email address: \\ Hamesohailu@gmail.com (H. Hameso), walelignworku@yahoo.co.uk (W. Worku), tednet2011@gmail.com (T. Ayalew)
}

\section{To cite this article:}

Hailu Hameso, Waleligh Worku, Tewodros Ayalew. Growth, Phenology and Yield Component of Barley (Hordeum vulgare L.) Genotypes as Affected by Fertilizer Types Under Acidic Soil. American Journal of Bioscience and Bioengineering. Vol. 9, No. 4, 2021, pp. 104-109. doi: $10.11648 /$ j.bio.20210904.12

Received: June 14, 2021; Accepted: July 10, 2021; Published: July 22, 2021

\begin{abstract}
Field experiment was conducted on acidic soil of Hagereselam, southern Ethiopiain 2019 cropping season to evaluate the growth and yield component formation performance of barley genotypes under different inorganic fertilizer types. Treatment consisting of four fertilizer types (control, NP, NPS and NPSB) and four barley genotypes (217176b, $240478,234911 \mathrm{~b}$ and 208855b) and one barley variety (HB- 1307) as a check laid out using a Randomized Complete Block Design with factorial arrangement with three replications Both main and interaction effects influenced days to physiological maturity, plant height, number of effective tillers $\mathrm{m}^{-2}$. However, days to heading, spike length, number of grain per spike and1000 grain weight, were only affected by main effects. Barley Genotype 217176b with NPSB fertilizer exhibited the longest plant height and better performance with regard to the remaining measured parameters. However, it did not significantly differ for the same parameters from the same genotype under NP and genotype 240478 with NPSB fertilizer application. The lowest performances were recorded from genotype $208855 \mathrm{~b}$ with no fertilizer application. Given the fact that the performance of growth, phenology and yield components between the two genotypes in combinations either with NPSB or NP is not statistically significant, either of the two genotypes with the NPSB or NP fertilizer is very essential for appropriate production of barley under acidic soils of Hagereselam and acidic soils of similar agro-ecologies in the highlands of Ethiopia.
\end{abstract}

Keywords: Barley Genotypes, Inorganic Fertilizer, Grain Yield, Soil Acidity

\section{Introduction}

Barely (Hordeum Vulgare L.) is one of the most important food crops produced in the world and ranking fourth in production area next to wheat, maize and rice [5]. It is the fifth important crop after maize, teff, sorghum and wheat in the Ethiopia [5]. Its grain is used for the preparation of different foodstuffs, such as injera, kolo, and local drinks, such as tela, borde and beer. The straw is used as animal feed, especially during the dry season. The national average yield of barley in Ethiopia is low (2.2 ton ha $\left.{ }^{-1}\right)$ [5].

Soil acidity is a critical issue requiring urgent attention in most highlands of Ethiopia because of its impact on crop production and productivity [15]. Soil acidity is a critical issue requiring urgent attention in most highlands of Ethiopia because of its impact on crop production and productivity [16]. The use of $\mathrm{N}$ fertilizers in the form of ammonia is a source of acidification [9]. The problem is common in all regions where precipitation is high enough to leach appreciable amounts of exchangeable bases from the soil surface [1]. According to [17] acidic soils tend to be deficient in $\mathrm{N}, \mathrm{P}$ and $\mathrm{S}$ which result in sever yield loses and deteriorated nutritional quality of the crops. Most acidic soils have poor chemical and biological properties. Its acidity associated with $\mathrm{Al}, \mathrm{H}, \mathrm{Fe}, \mathrm{Mn}$ toxicities to plant roots in the soil solutions and corresponding deficiencies of the available $\mathrm{P}, \mathrm{Mo}, \mathrm{Ca}, \mathrm{Mg}$ and $\mathrm{K}$ [13]. At $\mathrm{pH}$ below 5, $\mathrm{Al}$ is easily soluble in water and becomes the dominant ion in the soil solution. Soil acidity is expanding in scope and 
magnitude in Ethiopia, severely limiting crop production. For example, in barley, wheat and faba bean growing areas of central and southern Ethiopian highlands, farmers have shifted to producing oats which is more tolerant to soil acidity than wheat and barley [12].

Several practices have been recommended to reclaim soil acidity and upgrade the productivity of strongly acidic soils. These include the cultivation of acid tolerant varieties, covering the surface with non-acidic soil, the use of organic fertilizers, mineral fertilizers in a harmonized combination for sustainable production and liming for soil quality. However, continuous lime in soil is expensive and environmentally risky [26]. In this regard, the application of adequate mineral nutrition and use of acid tolerant varieties would be a suitable strategy for increase soil acidity related yield reduction. Therefore, this experiment was done to examine the response of barley genotypes, to inorganic fertilizers types under acidic soil and to evaluate and validate fertilizer types for the growth, phenology and yield components of barley under acidic soil at the study area.

\section{Materials and Methods}

\subsection{Description of Study Site}

This study was conducted at Hagerselam, southern Ethiopia during the main cropping seasons of 2019. Hagerselam is located at $38^{\circ} 27^{\prime} 44^{\prime \prime}$ E longitude and $06^{\circ} 26^{\prime} 59^{\prime \prime}, \mathrm{N}$ latitude. The altitude of the experimental site is $2648 \mathrm{~m}$ a s 1 . The climate of the site is sub-humid type with bi-modal rainfall pattern. The main rainy season is extends from June to September and mean annual precipitation of the site range from 1000-to- $1300 \mathrm{~mm}$.

\subsection{Soil Analysis}

For soil analysis, before planting twenty soil samples were randomly taken from the experimental site at a depth of $0-20$ $\mathrm{cm}$ using an auger and the samples were mixed thoroughly to produce one representative composite sample of $1 \mathrm{~kg}$. Samples were also taken later at harvest from each plot and composite same of $1 \mathrm{~kg}$ was produced on treatment basis rather than plot base.

\subsection{Experimental Methods}

Factorial experiment consisting of four fertilizer types (control, DAP, NPS, NPSB), and four barley genotypes from Ethiopian Biodiversity institute $(217176 \mathrm{~b}, 240478$ and 234911b 208855b) and one variety (HB-1307) were used as experimental material.

A Total of 20 treatments combination was laid out in RCBD with three replications. The spacing between plots and block was $0.5 \mathrm{~m}$ and $1 \mathrm{~m}$, respectively. The plot size was $1.6 \times 1.5 \mathrm{~m}$ $\left(2.4 \mathrm{~m}^{2}\right)$ accommodating eight rows of barley seed was sown at a spacing of $20 \mathrm{~cm}$ between rows. The recommended rates of NPS at $100 \mathrm{~kg} \mathrm{ha}^{-1} \mathrm{NPSB}$ at $100 \mathrm{~kg} \mathrm{ha}^{-1,}$ and DAP at $100 \mathrm{~kg}$ $\mathrm{ha}^{-1}$ fertilizer were applied as basal dressing at the time of sowing barley.

Table 1. Description of varieties used in this study.

\begin{tabular}{llll}
\hline \multirow{2}{*}{ Genotypes } & \multicolumn{1}{c}{ Collected area } \\
\cline { 2 - 3 } & Region & Keficho Shekicho & Woreda \\
\hline $217176 \mathrm{~b}$ & Southern Ethiopia & Decha \\
240478 & Southern Ethiopia & Chena \\
$234911 \mathrm{~b}$ & Southern Ethiopia & Masha Anderacha & Hagereselam \\
$208855 \mathrm{~b}$ & Sidama region & \\
HB-1307 (variety) & Released by Holetta Agricultural Research Centre at 206 & \\
\hline
\end{tabular}

Table 2. Types and the nutrient contents of the fertilizers used for the experiment.

\begin{tabular}{lllll}
\hline Types of fertilizers & $\mathbf{N}\left(\mathbf{k g ~ h a}-^{-1}\right)$ & $\mathbf{P}_{2} \mathbf{O}_{\mathbf{5}}\left(\mathbf{k g ~ h a}^{-\mathbf{1}}\right)$ & $\mathbf{S}\left(\mathbf{k g ~ h a}^{-\mathbf{1}}\right)$ & $\mathbf{B}\left(\mathbf{k g ~ h a}{ }^{-\mathbf{1}}\right)$ \\
\hline Control & 46 & 0 & 0 & 0 \\
NP & 64 & 46 & - & - \\
NPS & 65 & 38 & 7 & - \\
NPSB & 64.9 & 37.7 & 6.95 & 0.1 \\
\hline
\end{tabular}

\subsection{Data Collection and Analysis}

Days to emergence, Day to heading and Days to maturity were determined by counting the number of days from sowing to the time when the plants reached to each of phonological stage through visual observation. Five plants were randomly selected and plant height was measured at physiological maturity from the ground level to the tip of panicle from middle six harvestable rows in each plot

Spike length was measured by selecting five plants randomly from six rows at the node where the first spike branches emerge to the tip of the spike, then averaged. At stage of grain setting, the numbers of effective tillers were determined by counting the tillers from an area of $1 \mathrm{mx} 1 \mathrm{~m}$ plants by throwing a quadrant into the middle portion of each plot. Five ears were taken randomly from each plot and number grain/ spike, was measured at physiological maturity of the crop prior to harvest and The weight of 1000 seeds was determined by carefully counting the grains and weighing them using a sensitive balance.

\subsection{Data Analysis}

Data were subjected to ANOVA using SAS software version 9.0 (SAS, 2004). For parameters those ANOVA tested 
significant with respect to treatment effects, further means separation was done using least significant difference method (LSD) at 0.05 probability level.

\section{Results and Discussions}

\subsection{Physico-Chemical Properties of the Study Soil}

According to the laboratory analysis, the soil texture of the experimental area was dominated by clay. Thus, the texture of the soil was clay loam (table 3 ). The $\mathrm{pH}$ of the soil was 4.48 (Table 3) which was strongly acidic [25, 4] Have established a $\mathrm{pH}$ range of 5.5 to 7.0 to be associated with satisfactory availability of plant nutrients. Therefore, the soils of experimental site need reclamation to raise the $\mathrm{pH}$ and make them favorable for plant growth. The OC concentration of the study site was $2.38 \%$. [14] The categories for the OC content of soils are: Very low $(<2 \%)$, low (2-4), medium (4 - 10), high $(>10)$. Thus, the OC content of the soil is rated as low. Total nitrogen value of the experimental soil was $(0.14)$. According to EthioSIS [8] TN content $<0.1,0.1-0.15,0.15-0.3,0.3-0.5$, and $>0.5$ is rated as very low, low, medium, high and very high, respectively. Available P content of the experimental sit was $4.21 \mathrm{mg} \mathrm{kg}^{-1}$ (Table 3). EthioSIS [8] Suggest optimum P content for most Ethiopian soil as $15 \mathrm{mg} \mathrm{kg}^{-1}$. This low phosphorous content is due to intensive mining of the farm fields and fixation by heavy metals ( $\mathrm{Al}, \mathrm{Fe}$ and $\mathrm{Mn}$ ). [12] Reported that under acidic soil low content of $\mathrm{P}$ was due to fixation problem.

The CEC of the site was $19.78 \mathrm{cmol} \mathrm{kg}^{-1}$ (Table 3). [14] reported that soils having CEC of $>40,25-40,15-25,5-15,<5$ $\mathrm{cmol} \mathrm{kg}^{-1}$ are categorized as very high, high, medium, low and very low, respectively. According to the result obtained from soil laboratory, the value of CEC was in medium range. Available Boron in the study area was $0.47 \mathrm{mg} \mathrm{kg}^{-1}$ (Table 2). According to [8] critical $\mathrm{B}$ value for most Ethiopian soils is $0.8 \mathrm{mg} \mathrm{kg}^{-1}$. This shows that soils of the study area are deficit in B suggesting application for fertilizer which contains B. Intensive cultivation and crop residual removal in the area might be responsible for low B content of the soil.

Table 3. Physic- chemical Characteristics of the Experimental soil before sowing.

\begin{tabular}{|c|c|}
\hline Soil properties & Value \\
\hline Sand & $31 \%$ \\
\hline Silt & $32 \%$ \\
\hline Clay & $37 \%$ \\
\hline Texture class & Clay loam \\
\hline PH & 4.48 \\
\hline $\mathrm{OC}$ & 2.38 \\
\hline $\mathrm{TN} \%$ & 0.14 \\
\hline Available $\mathrm{P}\left(\mathrm{mg} \mathrm{kg}^{-1}\right)$ & 3.56 \\
\hline $\mathrm{B}\left(\mathrm{mg} \mathrm{kg}^{-1}\right)$ & 0.47 \\
\hline $\mathrm{CEC}\left(\mathrm{Cmol}(+) \mathrm{kg}^{-1}\right)$ & 19.78 \\
\hline Exchangeable acidity $\left(\mathrm{cmolc} \mathrm{kg}^{-1}\right)$ & 0.92 \\
\hline
\end{tabular}

\subsection{Crop Phenology}

\subsubsection{Days to Emergence and Heading}

Days to emergence was significantly $(\mathrm{P} \leq 0.001)$ affected by genotypes but not by the types of inorganic fertilizers and the interactions. The mean numbers of days required for emergence were between 6 to 9 days for the tested genotypes (Table 3). The shortest days to emergence was recorded from barley genotype 240478, while the longest day to emergence was recorded from HB-1307. Significant variation was not observed on days to emergence due to fertilizer application. This is due to the fact that, during germination the seedling mostly depends on stored food than on external nutrient. This is in conformity with the findings of [22] who reported that plants depend mostly on stored food than on external nutrients for germination and early establishment.

Days to heading was significantly $(\mathrm{P} \leq 0.001)$ affected by the main effects of genotypes and fertilizers, but the interaction effect was not significant for days to heading (Table 5). The shortest day to heading (56 days) was recorded from genotype 240478, while the longest day to heading (93 days) was recorded from HB-1307. This could be due to variation in genetic makeup. Similarly, [2] reported that barley genotypes differ in days to heading. This result is also in line with the findings of [2] on their work on participatory evaluation of barley genotypes for yield and other agronomic traits that showed significant difference among ten genotypes on both days to heading and maturity. All fertilized plots had relatively shorter days for heading compared to the control with no significant difference among the fertilizer types (Table 4). The lack of significant difference among the fertilizer types on days to heading might be due to the constant $\mathrm{N}$ and $\mathrm{P}$ level as $\mathrm{N}$ and $\mathrm{P}$ are the major nutrient affecting such phenological parameters. This result is in line with [7] who suggested that that the supply of $\mathrm{N}$ and $\mathrm{P}$ contribute to vigorous, rapid growth and early heading of wheat crop.

Table 4. Main Effects of Inorganic Fertilizers and Barley Genotypes on Days to Emergence and Heading under Acidic Soil, during cropping season of 2019.

\begin{tabular}{lll}
\hline Treatments & Day to Emergence & Day to Heading \\
\hline Types Fertilizers & & \\
Control & 8 & $78 \mathrm{a}$ \\
NP & 8 & $73 \mathrm{~b}$ \\
NPS & 8 & $72 \mathrm{~b}$ \\
NPSB & 8 & $71 \mathrm{~b}$ \\
Fertilizers & $\mathrm{ns}$ & $* * *$ \\
LSD & 2.9 & 1.15 \\
Genotypes & & \\
$217176 \mathrm{~b}$ & $7 \mathrm{c}$ & $65 \mathrm{e}$ \\
240478 & $6 \mathrm{~d}$ & $56 \mathrm{~d}$ \\
$234911 \mathrm{~b}$ & $8 \mathrm{~b}$ & $72 \mathrm{c}$ \\
$208855 \mathrm{~b}$ & $9 \mathrm{a}$ & $81 \mathrm{~b}$ \\
HB- 1307 & $9 \mathrm{a}$ & $93 \mathrm{a}$ \\
Genotypes & $* * *$ & $* * *$ \\
Genotypes* Fertilizers & $\mathrm{ns}$ & $\mathrm{ns}$ \\
CV & 2.89 & 2.13 \\
LSD & 0.19 & 1.29 \\
\hline
\end{tabular}

Means followed by the same letters are not significantly different at $(\mathrm{P} \leq 0.05)$

\subsubsection{Effects of Inorganic Fertilizers on Days to Physiological Maturity of Barley}

Days to physiological maturity was significantly $(\mathrm{P} \leq 0.001)$ affected by the main effects of genotypes, the types of 
inorganic fertilizers and by their interaction (Table 4). The number of days required to physiological maturity varied between 77 and 140 days among genotypes. Longest mean value of day to maturity was recorded from the check HB-1307 with no fertilizer application. The shortest day to maturity was recorded for barley genotype 240478 at NPSB followed by genotype 240478 with NP and NPS application. The significant difference among the genotypes for days to physiological maturity may be attributed to their genetic difference, which reflects their variable response to environmental conditions. Similarly, [28] reported that genotypes could differ in days required to attain at physiological maturity.

\subsection{Plant Height}

Analysis of variance showed that plant height was significantly $(\mathrm{P} \leq 0.001)$ affected by the main effects of barley genotypes, main effect of inorganic fertilizers and their interaction effect (Table 4)., mean value of genotypes for plant height ranged from $63 \mathrm{~cm}$ to $110 \mathrm{~cm}$. Similarly, longer plant heights of $110.287,109$ and $105.95 \mathrm{~cm}$ were recorded from genotype $217176 \mathrm{~b}$ with the applications of NPSB, NP and NPS respectively. There was no significant difference on the plant heights recorded from genotype $217176 \mathrm{~b}$ with fertilizers types and from genotype 240478 with NPSB and NP. The shorter plant heights were recorded from all genotypes with zero fertilizer application. The variation in the response may be due to differences in genetic makeup among the genotypes tested. [22] Reported that height of the crop is mainly controlled by the genetic makeup of a genotype and it can also be affected by the environmental factors.

Phosphorus application was reported to enhance plant growth, plant height, root collar diameter, and chlorophyll content in barley [20]. This result is in agreement with [18] and [27] who reported that plant height of barely was increase with application of $\mathrm{N}$ fertilizer. In line with this result, [6] reported that boron application had significant effect on the plant height of wheat showing a range of heights from $89.7-97.3 \mathrm{~cm}$. Boron is an essential micronutrient, which is reported to decrease the accumulation of toxic Al in several plants and enhance the nutrient uptake [24].

\subsection{Number of Effective Tillers}

The data revealed significant difference $(\mathrm{P} \leq 0.001)$ due to interaction effects of genotypes with types of inorganic fertilizers on effective tiller number. Higher mean number of effective tillers $\mathrm{m}^{-2}$ was recorded from genotype $217176 \mathrm{~b}$ treated with recommended NPSB, and this had no significant difference to that produced by $217176 \mathrm{~b}$ genotype with NP and NPS and also to that from genotype 240478 with Recommended NPSB. Whereas, the lower mean number of effective tillers were recorded from genotype $208855 \mathrm{~b}$ treated with all types of fertilizers and also from HB-1307 with no applied fertilizer (Table 5). Generally, genotype $217176 \mathrm{~b}$ tended to respond better to NSPB, NP, and NPS fertilization and also genotype 240478 for NPSB. This might be attributed to the different capacity of the genotypes in tillering and also due to nutrition. This is in agreement with that of [23], who reported significant difference among varieties for tillering. In line with this result, [11] reported that $\mathrm{N}$ and $\mathrm{P}$ fertilizer had potential role in number of total and effective tiller production per plant.

This variation could also happen due to the synergetic effects of boron nutrients increasing nitrogen nutrient use efficiency on genotype 240478. Boron is an essential micronutrient, which is reported to decrease the accumulation of toxic Al in several plants and increase nitrogen nutrient use efficiency [24]. Similarly, [3] reported that application of blended fertilizer brought significant difference in this parameter. The yield of crops is dependent upon the combined effect of many factors. Among these factors, the number of tillers per plant has a vital position, controlling yield of barley. The more the number of tillers, the better will be the stand of crop, which ultimately increase the yield.

Table 5. Interaction Effect of Barley Genotypes and Types of Inorganic Fertilizers on day to maturity Plant Height and Number of Effective Tillers.

\begin{tabular}{|c|c|c|c|}
\hline Treatments & $\begin{array}{l}\text { Day to } \\
\text { maturity }\end{array}$ & $\begin{array}{l}\text { Plant height } \\
\text { (cm) }\end{array}$ & $\begin{array}{l}\text { Effective tiller } \\
\left(\mathrm{m}^{-2}\right)\end{array}$ \\
\hline 217176b NPSB & $82^{\text {gh }}$ & $110.28^{\mathrm{a}}$ & $69.33^{\mathrm{a}}$ \\
\hline NP & $83^{\mathrm{fg}}$ & $109.03^{\mathrm{a}}$ & $65.33^{\mathrm{ab}}$ \\
\hline 240478 NPSB & $77^{i}$ & $108.86^{\mathrm{a}}$ & $65.0^{\mathrm{ab}}$ \\
\hline NP & $79^{\text {hi }}$ & $102.7 \mathrm{ab}$ & $59.3^{\text {bcd }}$ \\
\hline 217176b NPS & $82^{\mathrm{gh}}$ & $105.95 \mathrm{a}^{\mathrm{b}}$ & $62.3^{\mathrm{abc}}$ \\
\hline 240478 NPS & $83^{\mathrm{fg}}$ & $98.2 b^{c}$ & $58.6^{\text {bcd }}$ \\
\hline 234911b NPSB & $84^{\mathrm{f}}$ & $94.98^{\mathrm{cd}}$ & $55.3 \mathrm{~cd}$ \\
\hline NP & $85^{\mathrm{fg}}$ & $87.51^{\mathrm{de}}$ & $54.0^{\mathrm{d}}$ \\
\hline NPS & $86^{\mathrm{f}}$ & $85.59^{\mathrm{ef}}$ & $53.3^{\mathrm{d}}$ \\
\hline HB-1307 NPSB & $120^{\mathrm{b}}$ & $79.497^{\mathrm{fg}}$ & $36.33^{\mathrm{ef}}$ \\
\hline NP & $120^{\mathrm{b}}$ & $76.25^{\mathrm{gh}}$ & $36.0^{\mathrm{ef}}$ \\
\hline NPS & $120^{\mathrm{b}}$ & $75.98^{\mathrm{gh}}$ & $36.0^{\mathrm{ef}}$ \\
\hline 208855b NPSB & $99^{d}$ & $79.843^{\text {efg }}$ & $27.3^{\mathrm{gh}}$ \\
\hline NP & $100^{d}$ & $75.807^{\text {gh }}$ & $24.6^{\mathrm{gh}}$ \\
\hline NPS & $102^{\mathrm{d}}$ & $74.673^{\text {gh }}$ & $24.66^{\mathrm{gh}}$ \\
\hline $217176 b$ control & $90^{\mathrm{e}}$ & $71.24^{\mathrm{gh}}$ & $35.667^{\mathrm{ef}}$ \\
\hline 240478 control & $85 \mathrm{f}^{\mathrm{g}}$ & $73.81^{\mathrm{gh}}$ & $38.66^{\mathrm{e}}$ \\
\hline 234911 b control & $92^{\mathrm{e}}$ & $66.77^{\mathrm{hi}}$ & $30.33^{\text {ef }}$ \\
\hline HB-1307 control & $140^{\mathrm{a}}$ & $62.89^{\mathrm{i}}$ & $28.3^{\mathrm{gh}}$ \\
\hline 208855 b control & $106^{\mathrm{c}}$ & $68.61^{\mathrm{hi}}$ & $22.66^{\mathrm{h}}$ \\
\hline Interaction & & $* * *$ & $* * *$ \\
\hline $\mathrm{CV}$ & 2.306 & 5.69 & 9.55 \\
\hline LSD & 3.73 & 8.16 & 7.01 \\
\hline
\end{tabular}

Means followed by the same letters are not significantly different at $(\mathrm{P} \leq 0.05)$

\subsection{Spike Length}

Spike length was significantly $(\mathrm{p}<0.001)$ influenced by the main effects of inorganic fertilizers and genotypes, but not, by the interaction effect (Table 5). Genotype 217176b and 240478 produced longer spike length, however, the two genotypes do not differ for for the spike length and lower spike lengths were obtained from variety HB- 1307 and genotype 208855 b.

Longer spike lengths were recorded from the plots treated 
with recommended NPSB and NP application without significant difference between each other. These were improvements by 66.591 and $63.36 \%$ from NPSB and NP as compared to the shortest spike length $(6.72 \mathrm{~cm})$ obtained from zero fertilizer, respectively. The result indicated that macronutrient ( $\mathrm{N}, \mathrm{P}$ and $\mathrm{S}$ ) and micro nutrient (boron) might have enhanced spike length of plants. On other hand, nitrogen and phosphorus had played a major role for cell division and elongation. The result is in agreement with the results of [6]. (2011), [10] who reported that the spike length of wheat significantly increased as a result of applying B blended fertilizer with macro nutrients. [3] Also reported that, optimum application of balanced nutrients has significant effect on spike length growth.

\subsection{Number of Grain per Spike}

The analysis of variance showed that grain number per spike of barley was significantly influenced $(\mathrm{P} \leq 0.001)$ due to main effects of genotypes and different types of inorganic fertilizers but not interaction effect (Table 6). The highest mean numbers of grain per spike (46.23) was recorded from genotype $217176 \mathrm{~b}$ while the lowest mean (20.31), was obtained from genotype $208855 \mathrm{~b}$. This might be due to the presence of genetic difference among the tested genotypes. Reports have shown the variation in number of grain per spike as a function of differences in barely genotypes [21]. This result is also in agreement with that of [21] who reported significant difference among three varieties of wheat on number of kernels per spike and 1000 kernel weight.

The highest mean numbers of grain per spike (41.9) was recorded from NPSB while the lowest mean (26.12), was obtained from the zero fertilizer (Table 6). This could be due to enhanced uptake of nitrogen, phosphorus and sulfur resulting from blending the nutrients with Boron. [7] suggested that boron application has a key role in plant metabolism and root growth as contributes to better use of macro and micronutrients and synthesis of more carbohydrates and proteins. In agreement with this result [6] reported that Boron application enhanced a significant improvement in the number of seeds per spike of wheat.

\subsection{Thousand Grain Weight}

Analysis of variance revealed that thousand-grain weight was significantly different among the tested genotypes $(\mathrm{P} \leq$ 0.001), due to main effect of genotypes and types of inorganic fertilizers but no interaction effect.

Genotypes $217176 \mathrm{~b}$ produced the highest thousand-seed weight (38.03g) (Tables 5). On the contrary, the lowest value of thousand-grain weight $(27.74 \mathrm{~g})$ was recorded from 208855 b genotype. This may be due to the suitable genetic behavior of $217176 \mathrm{~b}$ that led to an increased photosynthesis process and accumulations of carbohydrate in seed to produce heavy kernels and consequently increased seed weight per spike. Similarly, [19] reported presence of variation in thousand grain weight among barely genotypes.
Greater thousand-grain weights were obtained from the recommended rates of NPSB and NP without statistically significant difference between the two treatments. The lowest grain weight $(20.96 \mathrm{~g})$ was obtained from the control. The absence of significant difference on thousand grain weights between NPSB and NP might be due to the constant application of major nutrients (N and $\mathrm{P}$ ) in both fertilizers, which play the major role in growth and development of a crop.

Table 6. Main Effect of Barley Genotypes and Types of Inorganic Fertilizers on Spike Length (SL), Number of Grain per Spike (NGS) and Thousand Grain Weight (TGW) under acidic soil.

\begin{tabular}{llll}
\hline Treatments & Spike length & $\begin{array}{l}\text { Grain per } \\
\text { spike }\end{array}$ & $\begin{array}{l}\text { 1000 grain } \\
\text { weight }\end{array}$ \\
\hline Fertilizers types & & & \\
NPSB & $9.9093^{\mathrm{a}}$ & $41.901^{\mathrm{a}}$ & $37.5120^{\mathrm{a}}$ \\
NP & $9.4320^{\mathrm{ab}}$ & $39.351^{\mathrm{b}}$ & $36.2160^{\mathrm{ab}}$ \\
NPS & $8.8880^{\mathrm{b}}$ & $38.416^{\mathrm{b}}$ & $35.5847^{\mathrm{b}}$ \\
Control & $6.7213^{\mathrm{c}}$ & $26.120^{\mathrm{c}}$ & $20.9560^{\mathrm{c}}$ \\
Fertilizer & $* * *$ & $* * *$ & $* * *$ \\
LSD & 0.72 & 2.33 & 1.47 \\
Genotypes & & & \\
$217176 \mathrm{~b}$ & $10.9858^{\mathrm{a}}$ & $46.231^{\mathrm{a}}$ & $38.0333^{\mathrm{a}}$ \\
240478 & $10.3292^{\mathrm{a}}$ & $43.502^{\mathrm{b}}$ & $35.9700^{\mathrm{b}}$ \\
234911b & $8.2367^{\mathrm{b}}$ & $39.474^{\mathrm{c}}$ & $31.1600^{\mathrm{c}}$ \\
208855b & $6.8425^{\mathrm{c}}$ & $32.723^{\mathrm{d}}$ & $29.9300^{\mathrm{c}}$ \\
HB- 1307 & $7.294^{\mathrm{c}}$ & $20.306^{\mathrm{e}}$ & $27.7425^{\mathrm{d}}$ \\
Genotype & $* * *$ & $* * *$ & $* * *$ \\
Fertilizer x genotypes & $\mathrm{Ns}$ & $\mathrm{ns}$ & $\mathrm{Ns}$ \\
CV & 11.26 & 8.65 & 6.11 \\
LSD & 0.81 & 2.6 & 1.64 \\
\hline
\end{tabular}

Means followed by the same letters are not significantly different at $(\mathrm{P} \leq 0.05)$

\section{Conclusion}

Information on barley response to inorganic fertilizer types is crucial to come up with barley production under acidic soil. To evaluate the performance of barley genotypes in terms of growth, phenology and yield components with inorganic fertilizer types under acidic soil. The day to emergence, the day to heading were affected by the main effects. But day to physiological maturity was affected by interaction effect. The tallest plant height and highest mean number of effective tillers $\mathrm{m}^{-2} 217176 \mathrm{~b}$ at NPSB, NP and NPS respectively without significant difference among each other and also genotype 240478 with NPSB. Genotypes $217176 \mathrm{~b}$ and 240478 treated with NPSB and NP produced longer spike. The highest mean numbers of grain per spike and thousand-grain weight were recorded from genotype $217176 \mathrm{~b}$ and recommended rate of NPSB as well as NP.

Given the fact that growth, phenology and yield components of barley between the two genotypes in combination with either NPSB or NP can be recommended for production of barley in acidic soils of Hagereselam and similar agro-ecologies in the highlands of Ethiopia. Therefore, it would be too early to reach at a conclusive recommendation since the current study was carried out only in one location for one cropping season. Hence, further studies replicated over seasons and across locations are needed to recommend 
optimum types of inorganic fertilizer with better growth, phenology and yield components to come up with improved productivity of barely varieties.

\section{References}

[1] Achalu C, Heluf G, Kibebew K, Abi T 2012. Response of barley to liming of acid soils collected from different land use systems of Western Oromia, Ethiopia. J. Biodiv. Environ. Sci. 2 (7): 1-13.

[2] Aynewa Y., Tadesse D. and Wondimu B. 2013. Participatory evaluation of malt barley (Hordeum vulgare L.) genotypes for yield and other agronomic traits at North-West Ethiopia. Wudpecker Journal of Agricultural Research. Vol. 2 (8), pp. 218 - 222, August 2013.

[3] Berhan Abayu 2012. Agronomic and Economic Effects of Blended Fertilizers Under Planting Method on Yield and Yield Components of Tef: M. Sc Thesis, Mekelle University, Mekelle, Ethiopia.

[4] Brady, N. C. and Weil, RR 2002. The nature and properties of soils thirteenth edition Prentice Hall, New Jersey.

[5] CSA (Central Statistical Agency) 2018. Central Statistical Agency agricultural sample survey report on area and production of major crops private peasant holdings, meher season. Addis Ababa, Ethiopia. Volume I.

[6] Debnath, M. R., Jahiruddin M., Rahman, M. M. and Haque, M. A 2011. Determining optimum rate of boron application for higher yield of wheat in Old Brahmaputra Flood plain soil. J. Bangladesh Agril. Univ. 9 (2): 205-210.

[7] Debritu Tola 2013. Soil fertility characterization and evaluation of blended fertilizer for wheat (Triticum aestivum L.) production on vertisols of Woliso district, South Western Ethiopia. M. Sc. Thesis, Haramaya University, Haramaya, Ethiopia.

[8] EthioSIS (Ethiopian Soil Information System) 2014. Soil Fertility and fertilizer recommendation Atlas of Tigray Region. Ministry of Agriculture (MoA) and Agricultural Transformation Agency (ATA).

[9] Fageria, N. K., and Nascente, A. S 2014. Management of soil acidity of South American soils for sustainable crop production. Adv. Agron. 128, 221-275.

[10] Fayera Asefa, AdugnaDebela and Muktar Mohammed 2014. Evaluation of Tef [Eragrostistef (zuccagni). Trotter] Responses to Different Rates of NPK Along With Zn and B in Didessa District, South western Ethiopia. World Applied Sciences Journal, 32 (11): 2245-2249.

[11] Firehiwot Getachew 2014. Effect of vermicompost and inorganic $\mathrm{N}$ and $\mathrm{P}$ fertilizers on growth, yield, and quality of bread wheat (Triticum aestivum L). in eastern Ethiopia M. Sc. Thesis, Haramaya University, Haramaya, Ethiopia.

[12] Habtamu Admas, 2015. Reclamation of Phosphorus Fixation by Organic Matter in Acidic Soils. Global Journal of Agricultural Science, 3 (6): 271-78.

[13] Kisinyo, P. O., Opala, P. A. Gudu, S. O. Othieno, C. O. Okalebo, J. R. Palapala, V., Otinga, A. N., 2014. Recent advances towards understanding Kenyan acid soils for improved crop production. African Journal of Agricultural
Research 9 (31): 2397-2408.

[14] Landon JR 2014. Booker Tropical Soil Manual. A handbook for soil survey and agricultural land evaluation in the tropics and sub tropics. John Wiley and Sons, New York. P 474.

[15] Martin, JH, Walden RP, Stamp DL 2006. Principle of field crop production. Pearson Education, Inc.

[16] Melese, A., Yli-Halla, M., 2016. Effects of applications of lime, wood ash, manure and mineral $\mathrm{P}$ fertilizer on the inorganic $\mathrm{P}$ fractions and other selected soil chemical properties on acid soil of Farta District, northwestern highland of Ethiopia. African Journal of Agricultural Research 11 (2): 87-99.

[17] Mesfin A 2007. Nature and management of acid soils in Ethiopia. Addis Ababa, Ethiopia. P 99.

[18] Minella E, Sorrells ME 1992. Aluminium tolerance in barley: genetic relationships among genotypes of diverse origin. Crop Sci. 1992; 32: 593-598.

[19] Rashid, A., Khan, U. K. and Khan, D. J 2008. Comparative effect of varieties and fertilizer levels on barley (Hordeum vulgare L). Pakistan Journal of Soil Science, 1: 1-13.

[20] Razaq M., Zhang P., Shen H. L 2017. Salahuddin Influence of nitrogen and phosphorous on the growth and root morphology of Acer mono. PLoS ONE. 2017; 12: e0171321. doi: 10.1371/journal.pone.0171321.

[21] Ryan, P. R., Raman, H., Gupta, S., Horst, W. J., and Delhaize, E 2009. A second mechanism for aluminum resistance in wheat relies on the constitutive efflux of citrate from roots. Plant Physiol. 149, 340-351.

[22] Shrivastava BK, MP Singh, SK Jain 1992. Effect of spacing and nitrogen levels on growth, yield and quality of seed crops of radish. Seed Res., 20: 85-7.

[23] Suleiman A., Nganya J., and Ashraf M 2014. Effect of Cultivar and Sowing Date on Growth and Yield of Wheat (Triticum aestivum L). In Khartoum, Sudan: Journal of Forest Products \& Industries, 3 (4): 198-203.

[24] Tahir M, Tanveer A, Shah TH, Fiaz N, Wasaya A 2009. Yield Response of Wheat (Triticuma estivum L.) to Boron Application at Different Growth Stages. Pak. J. Life Soc. Sci. 7: 39-42.

[25] Tekalign Tadesse 1991. Soil, Plant, fertilizer, animal manure and compost analysis manual. International Livestock centre for Africa, No. B13. Addis Ababa, Ethiopia.

[26] Vance C. P., Uhde-Stone C., Allan D. L 2003. Phosphorus acquisition and use: Critical adaptations by plants for securing a nonrenewable resource. New Phytol. 2003; 157: 423-447. doi: $10.1046 /$ j.1469-8137.2003.00695.

[27] Wakene T., Walelign W. and Wassie H 2014. Effects of nitrogen and phosphorus fertilizer levels on growth and development of barley (Hordeum vulgare L.) at Bore District, Southern Oromia, Ethiopia. American Journal of Life Sciences 2 (5): 260-266.

[28] Wosene Abtew and Berhane Lakew 2015. Ethiopian barley landraces show higher yield stability and comparable yield to improved varieties in multi environment field trials. Journals of Plant Breeding and Crop Science, 7 (8): 1-17. 